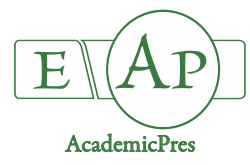

\title{
Effect of Irrigation and Fertilization Levels on Mineral Composition of Cannabis sativa L. Leaves
}

\author{
Eleni WOGIATZI ${ }^{1 *}$, Nikolaos GOUGOULIAS ${ }^{1}$, \\ Kyriakos D. GIANNOULIS ${ }^{1,2}$, Christina-Anna KAMVOUKOU ${ }^{1,3}$ \\ ${ }^{1}$ Technological Educational Institute of Thessaly, Department of Agronomy Technology, 41100 Larissa, Greece; wogiatzi@teilar.gr \\ ('corresponding author);ngougoulias@teilar.gr; kyriakos.giannoulis@gmail.com; cakamvoukou@gmi.com \\ ${ }^{2}$ University of Thessaly, Department of Agriculture, Crop Production and Rural Environment, Laboratory of Agronomy and Applied Crop \\ Physiology, Fytokoy Str., 38446 Volos, Greece; kyriakos.giannoulis@gmail.com \\ ${ }^{3}$ Aristotle University of Thessaloniki, School of Pharmacy, Greece; cakamvoukou@gmi.com
}

\begin{abstract}
A field experiment was conducted in central Greece to study, the effect of two irrigation (I1: 100\% ETo, I2: 60\% ETo) and $\mathrm{N}$-fertilization levels (N1: 244, N2: $184 \mathrm{~kg} \mathrm{ha}^{-1}$ ), on the nutrients concentration of Cannabis sativa leaves (cv. 'Fibranova'). The N, K, Ca, Mg, P -concentration in the leaves was ranged by 2.8 to $3.51 \%, 1.8$ to $2.57 \%, 1.96$ to $2.17 \%, 0.86$ to $0.88 \%$, and 0.3 to $0.37 \%$ respectively, while by the micronutrients the iron showed the highest concentration that ranged by 129 to 139.8 $\mathrm{mg} \mathrm{kg}^{-1} \mathrm{dw}$. The treatment I1F1, where the highest level of irrigation and $\mathrm{N}$-fertilization was applied, compared to the other treatments, showed the highest dry biomass yield, however, in the leaves the highest concentrations of $\mathrm{N}, \mathrm{K}, \mathrm{Mn}$ and $\mathrm{Cu}$ were not observed. Moreover, it was found that the N, K, Ca, Mg, P and Fe removal only by one ton dry biomass of leaves was ranged by 28 to $35.12 \mathrm{~kg}, 18.01$ to $25.65 \mathrm{~kg}, 19.6$ to $21.7 \mathrm{~kg}, 8.34$ to $8.75 \mathrm{~kg}, 3.01$ to $3.70 \mathrm{~kg}$ and 0.129 to $0.140 \mathrm{~kg}$, respectively. These results could contribute optimal fertilizer application and therefore to the reduction of production costs of the crop.
\end{abstract}

Keywords: cannabis; fertilization; irrigation; mineral composition; nutrient uptake

\section{Introduction}

Cannabis sativa is an annual herbaceous crop cultivated in a wide range environmental conditions for its fiber production, medicine, as fuel source, and as raw material for thermal insulation (Small and Marcus, 2002; Van der Werf and Turunen, 2008; Bertoli et al., 2010; Mihoc et al., 2012).

Although all hemp varieties contain psychoactive compounds as $\Delta$ 9-tetrahydrocannabinol (THC), the fiber hemp varieties contain low concentration, and in the European Union, the majority of the countries, have

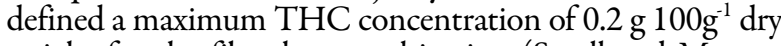
weight for the fiber hemp cultivation (Small and Marcus, 2003).

During the last years hemp cultivation has increased significantly in Europe, because it has a positive environmental impact, can be used as an alternative rotation crop, can improve soil structure and preserving soil fertility(Bertoli et al., 2010; Zatta et al., 2012; Bouloc and Werf, 2013; Finnan and Styles, 2013).
Hemp crop yield and quality of hemp products is influenced significantly by hemp cultivars, agro-technical methods, soil properties, and climate. Therefore, is important the choice of the appropriate hemp variety in an area (Amaducci et al., 2012; Cosentino et al., 2012; Tang et al., 2016).

Intake of the nutrient elements from the plant affects the biomass production and the amounts of available soil nutrients. However, there is little literature on the mineral composition of fibre hemp, in order to optimize the mineral fertilization, mainly when is cultivated under Mediterranean conditions (Hakala et al., 2009; Angelini et al., 2014).

The objective of the present study was the effect of irrigation and fertilization levels on the macronutrients and micronutrients of Cannabis sativa leaves (variety 'Fibranova'), in order to set up removal amounts from the leaves and to optimize mineral fertilization, under the Mediterranean conditions of Thessaly region, central Greece. 
1074

\section{Materials and Methods}

\section{Experimental}

The experiment was conducted at the Experimental Farm of the Technological Educational Institute of Thessaly, Larissa (latitude 39 62'69" N, longitude $22^{\circ} 38^{\prime} 14^{\prime \prime}$ E). The seeding took place on April 2017 applying $45 \mathrm{~kg} \mathrm{ha}^{-1}$ of seed cultivar 'Fibranova' in a rowdistance of $12.5 \mathrm{~cm}$. The crop density was 160 plants $\mathrm{m}^{-2}$. Two levels of irrigation ( $\mathrm{I} 1=100 \%$ ETo and $\mathrm{I} 2=60 \% \mathrm{ETo})$, and two levels of fertilization $\left(\mathrm{F} 1=244 \mathrm{~kg} \mathrm{~N}, 60 \mathrm{~kg} \mathrm{P}_{2} \mathrm{O}_{5}\right.$ and $60 \mathrm{~kg} \mathrm{~K} \mathrm{~K}_{2} \mathrm{O}$ and F2=184 $\mathrm{kg} \mathrm{N}, 60 \mathrm{~kg} \mathrm{P} \mathrm{O}_{5}$ and $60 \mathrm{~kg}$ $\mathrm{K}_{2} \mathrm{O}$ per hectare) were applied. The evapotranspiration (ETo) in the area was $500 \mathrm{~mm}$. Thus, hemp cultivation consists of four experimental units, I1F1, I1F2, I2F1 and I2F2. The size on each experimental unit was $14 \mathrm{~m}^{2}$ with four replications. The study area is characterized by a typical Mediterranean climate with cold winter, hot summer and low precipitation in spring and summer. In particular, during the growing period of hemp, the average temperature ranged to $22.9^{\circ} \mathrm{C}$, while the precipitation was $290 \mathrm{~mm}$.

\section{Methods of analyses}

The Texture of soils was determined by the bouyoucos hydrometer method (Bouyoucos, 1962). Soil samples were analyzed using the following methods which are referred by (Page et al., 1982).

Soil $\mathrm{pH}$ is determined in (1:5) soil/water extract; $\mathrm{pH}$ value is measured by using glass electrode $\mathrm{pH}$ meter. Electrical conductivity, (EC) measured in (1:5) soil/water extract; using conductivity meter. The calcium carbonate was determined by the method Bernard. Organic matter was analyzed by chemical oxidation with $1 \mathrm{~mol} \mathrm{~L}^{-1} \mathrm{~K}_{2} \mathrm{Cr}_{2} \mathrm{O}_{7}$ and titration of the remaining reagent with $0.5 \mathrm{~mol} \mathrm{~L}^{-1}$ $\mathrm{FeSO}_{4}$.

Both ammonium and nitrate nitrogen were extracted with $0.5 \mathrm{~mol} \mathrm{~L}^{-1} \mathrm{CaCl}_{2}$ and estimated by distillation in the presence of $\mathrm{MgO}$ and Devarda's alloy, respectively. Exchangeable forms of potassium and sodium were extracted with $1 \mathrm{~mol} \mathrm{~L}^{-1} \mathrm{CH}_{3} \mathrm{COONH}_{4}$ and measured by flame Photometer (Essex, UK). Available $\mathrm{P}$ forms was extracted with $0.5 \mathrm{~mol} \mathrm{~L}^{-1} \mathrm{NaHCO}_{3}$ and measured colorimetrically. Available forms of $\mathrm{Cu}, \mathrm{Zn}, \mathrm{Mn}$ and $\mathrm{Fe}$ were extracted with DTPA (diethylenetriaminepentaacetic acid $0.005 \mathrm{~mol} \mathrm{~L}^{-1}+\mathrm{CaCl}_{2} 0.01 \mathrm{~mol} \mathrm{~L}^{-1}+$ triethanolamine $0.1 \mathrm{~mol} \mathrm{~L}^{-1}$ ) and measured by atomic absorption. The samples were analyzed by Atomic Absorption, Spectroscopy Varian Spectra AA 10 plus, Victoria, Australia, with the use of flame and air-acetylene mixture (Varian, 1989).

Dried samples of hemp were ground in a rotor mill to < $300 \mu \mathrm{m}$ prior the analysis. The minerals in plant tissues were determined by dry combustion according to the methods described by (Jones and Case, 1990).Total nitrogen content in leaves was measured using the Kjeldhal method described by Jones (Jones, 1998).

\section{Statistical analysis}

Data analysis was made using the MINITAB (Ryan et al., 2005) statistical package. Analysis of variance was used to assess treatments effect. Mean separation was made using
Tukey's test when significant differences $(\mathrm{P}=0.05)$ between treatments were found.

\section{Results and Discussion}

\section{Soil physical-chemical characteristics}

The soil of the experimental field before hemp's sowing at depth 0-30 $\mathrm{cm}$ was characterized as Sandy Clay Loam (SCL), bulk specific gravity of soil was $1.3 \mathrm{~g} \mathrm{~cm}^{-3}$, the $\mathrm{pH}$ at (1:5) soil/water extract was 7.26, while the electrical conductivity measured in the same extract was $0.2 \mathrm{~ms} / \mathrm{cm}$, organic matter and $\mathrm{CaCO}_{3}$ soil content was $1.44 \%$ and $2.42 \%$, respectively. Moreover, the exchangeable Na content and the cation-exchange capacity (CEC) of soil was 103.5 $\mathrm{mg} \mathrm{kg}^{-1}$ and $19.3 \mathrm{cmolkg}^{-1}$, respectively. The exchangeable Ca and $\mathrm{Mg}$ soil content was $1988 \mathrm{mg} \mathrm{kg}^{-1}$ and $397.5 \mathrm{mg} \mathrm{kg}^{-1}$, respectively. Finally, the levels of available mineral nutrient elements $\mathrm{N}, \mathrm{P}, \mathrm{K}, \mathrm{Cu}, \mathrm{Zn}, \mathrm{Mn}$, and Fe before hemp sowing and after the crop harvest are presented in Table 1 and Fig. 1. According to other studies, the hemp crop requires slightly alkaline and well-drained soils, rich in nutrients and organic matter (Struik et al., 2000).

The soil inorganic nitrogen content $\left(\mathrm{N}-\mathrm{NH}_{4}^{+}+\mathrm{N}-\right.$ $\mathrm{NO}_{3}{ }^{-}$) showed a decrease in all treatments at the end of the crop period (harvest) compared with the begin of the crop period, part of this decrease is likely due to plant nitrogen uptake and in leaching to lower soil layers. The lower inorganic nitrogen content at the end of the crop period compared with the begin of the crop period was observed in treatments I1F2 and I2F2, where the smallest nitrogen fertilizer dose was added, irrespective of the irrigation levels (Table 1 and Fig. 1).

The available phosphorus (Olsen) content of soil increased at the end of the crop period compared with the beginning of crop period in the treatment $\mathrm{I} 2 \mathrm{~F} 1$, where the lowest level of irrigation was applied. This increase to available phosphorus content is probably due to the lower phosphorus leaching or in lower uptake by the plant, and not only in the added phosphorus fertilizer. On the contrary, the available phosphorus content decreased at end of the crop period compared with the beginning of crop period for the treatment I1F2, where the higher level of irrigation was applied. This decrease to available phosphorus content is probably due to greater phosphorus leaching or in increased uptake by the plant. In the other treatments, the available soil phosphorus content did not show statistically significant differences at end of the crop period compared with the beginning of the crop period (Table 1 and Fig. 1).

The levels of the available forms $\mathrm{K}$ and $\mathrm{Mn}$ in the soil showed a decrease at end of the crop period compared with the beginning of the crop period for treatments I1F1 and I1F2, where the higher level of irrigation was applied. This decrease to available forms $\mathrm{K}$ and $\mathrm{Mn}$ is probably due to greater leaching of the mineral elements or in increased uptake by the plant. Finally, the levels of the available forms $\mathrm{Cu}, \mathrm{Zn}$ and $\mathrm{Fe}$ of soil for all treatments did not show statistically significant differences at end of the crop period compared with the begin of the crop period (Table 1 and Fig. 1). The inorganic $\mathrm{N}, \mathrm{P}_{2} \mathrm{O}_{5}$, and $\mathrm{K}_{2} \mathrm{O}$ concentrations were transformed to nutrient contents presented in Table 2 and Fig. 2 using the following equation: 
Nutrient content $\left(\mathrm{kg} \mathrm{ha}^{-1}\right)=$ nutrient concentration $(\mathrm{kg}$ $\left.10^{-6} \mathrm{~kg}^{-1}\right) \times 1300\left(\mathrm{~kg} \mathrm{~m}^{-3}\right) \times 10^{4}\left(\mathrm{~m}^{2} \mathrm{ha}^{-1}\right) \times 0.3(\mathrm{~m})$

Where:

$1300 \mathrm{~kg} \mathrm{~m}^{-3}$ is the soil bulk density value.

It is important to refer that the concentrations of available $\mathrm{P}$ and $\mathrm{K}$ forms, first were transformed in concentrations of $\mathrm{P}_{2} \mathrm{O}_{5}$, and $\mathrm{K}_{2} \mathrm{O}$.

Table 2 and Fig. 2, shows the balance of mineral nutrient elements in the soil at depth of $0-30 \mathrm{~cm}$, during the cultivation period. Our results confirm the high demands of the cannabis in available forms of $\mathrm{N}$ and $\mathrm{K}$ during the growing period.

Table 1. Levels of nutrient elements in soil before hemp sowing and after the crop harvest at soil depth 0-30 cm

\begin{tabular}{|c|c|c|c|c|c|c|c|}
\hline \multirow{3}{*}{ Treatments } & \multicolumn{3}{|c|}{ Available forms } & \multicolumn{4}{|c|}{ DTPA } \\
\hline & $\mathrm{N}$ & $\mathrm{P}$ & $\mathrm{K}$ & $\mathrm{Cu}$ & $\mathrm{Zn}$ & $\mathrm{Mn}$ & $\mathrm{Fe}$ \\
\hline & \multicolumn{7}{|c|}{$\mathrm{mg} \mathrm{kg}^{-1}$ soil } \\
\hline \multicolumn{8}{|c|}{ Before hemp sowing } \\
\hline & $381.5 \pm 29.3^{\mathrm{a}}$ & $17.2 \pm 1.12^{\mathrm{bc}}$ & $555.8 \pm 23.4^{2}$ & $0.93 \pm 0.07^{\mathrm{a}}$ & $0.70 \pm 0.05^{\mathrm{a}}$ & $4.92 \pm 0.37^{\mathrm{a}}$ & $0.37 \pm 0.03^{\mathrm{a}}$ \\
\hline \multicolumn{8}{|c|}{ After crop harvest } \\
\hline IIF1 & $171.5 \pm 12.7^{b}$ & $18.7 \pm 1.29^{\mathrm{b}}$ & $432.4 \pm 16.0^{b}$ & $0.85 \pm 0.05^{\mathrm{a}}$ & $0.78 \pm 0.07^{\mathrm{a}}$ & $2.96 \pm 0.21^{b}$ & $0.30 \pm 0.02^{\mathrm{a}}$ \\
\hline I1F2 & $54.5 \pm 4.54^{d}$ & $13.9 \pm 0.84^{\mathrm{d}}$ & $462.6 \pm 16.1^{b}$ & $0.92 \pm 0.06^{\mathrm{a}}$ & $0.64 \pm 0.05^{\mathrm{a}}$ & $3.11 \pm 0.20^{b}$ & $0.32 \pm 0.02^{\mathrm{a}}$ \\
\hline $\mathrm{I} 2 \mathrm{~F} 1$ & $118.5 \pm 8.78^{c}$ & $21.8 \pm 1.23^{\mathrm{a}}$ & $512.9 \pm 17.6^{a}$ & $0.85 \pm 0.06^{a}$ & $0.46 \pm 0.04^{a}$ & $4.15 \pm 0.29^{\mathrm{a}}$ & $0.37 \pm 0.03^{\mathrm{a}}$ \\
\hline $\mathrm{I} 2 \mathrm{~F} 2$ & $66.5 \pm 5.45^{\mathrm{d}}$ & $15.5 \pm 1.17^{\mathrm{cd}}$ & $512.9 \pm 18.5^{a}$ & $0.85 \pm 0.05^{\mathrm{a}}$ & $0.55 \pm 0.05^{\mathrm{a}}$ & $4.26 \pm 0.31^{a}$ & $0.37 \pm 0.03^{a}$ \\
\hline
\end{tabular}

Data represent average means and SE deviation, $\mathrm{n}=(4)$; For each chemical property of soil, columns of the table with the same letter do not differ significantly according to the Tukey's test $(\mathrm{P}=0.05) . \mathrm{I} 1=100 \% \mathrm{ETo} ; \mathrm{I}=60 \% \mathrm{ETo} ; \mathrm{F} 1=244 \mathrm{~kg} \mathrm{~N}, 60 \mathrm{~kg}$ P2O5 and $60 \mathrm{~kg}$ K2O per hectare; F2=184 kg N, $60 \mathrm{~kg}$ P2O5 and $60 \mathrm{~kg} \mathrm{K2O} \mathrm{per}$ hertare

Table 2. Balance of mineral nutrient elements in the soil at depth $(0-30) \mathrm{cm}$

\begin{tabular}{|c|c|c|c|}
\hline \multirow{2}{*}{ Treatments } & Mineral-N & Available- $\mathrm{P}_{2} \mathrm{O}_{5}$ & Available- $\mathrm{K}_{2} \mathrm{O}$ \\
\hline & \multicolumn{3}{|c|}{$\mathrm{kgha}^{-1}$} \\
\hline \multicolumn{4}{|c|}{ Start of growing period } \\
\hline & $1488 \pm 114.46$ & $153.6 \pm 10.04$ & $2612.3 \pm 109.76$ \\
\hline \multicolumn{4}{|c|}{ Added fertilization } \\
\hline $\mathrm{I1F} 1$ & 244 & 60 & 60 \\
\hline I1F2 & 184 & 60 & 60 \\
\hline $\mathrm{I} 2 \mathrm{~F} 1$ & 244 & 60 & 60 \\
\hline $\mathrm{I} 2 \mathrm{~F} 2$ & 184 & 60 & 60 \\
\hline \multicolumn{4}{|c|}{ End of growing period } \\
\hline $\mathrm{I1F} 1$ & $668.9 \pm 49.55$ & $167.0 \pm 11.53$ & $2032.3 \pm 75.02$ \\
\hline I1F2 & $212.6 \pm 17.72$ & $124.2 \pm 7.51$ & $2174.2 \pm 75.49$ \\
\hline $\mathrm{I} 2 \mathrm{~F} 1$ & $462.2 \pm 34.24$ & $194.7 \pm 10.99$ & $2410.6 \pm 82.87$ \\
\hline $\mathrm{I} 2 \mathrm{~F} 2$ & $259.4 \pm 21.26$ & $138.5 \pm 10.46$ & $2410.6 \pm 86.74$ \\
\hline
\end{tabular}

Data represent average means and SE deviation, $\mathrm{n}=(4) ; \mathrm{Il}=100 \% \mathrm{ETo} ; \mathrm{I}=60 \% \mathrm{ETo} ; \mathrm{F} 1=244 \mathrm{~kg} \mathrm{~N}, 60 \mathrm{~kg} \mathrm{P}_{2} \mathrm{O}_{5}$ and $60 \mathrm{~kg} \mathrm{~K} 2 \mathrm{O}$ per hectare; F2=184 kg N, $60 \mathrm{~kg} \mathrm{P} 2 \mathrm{O}_{5}$ and $60 \mathrm{~kg} \mathrm{~K} 2 \mathrm{O}$ per hectare
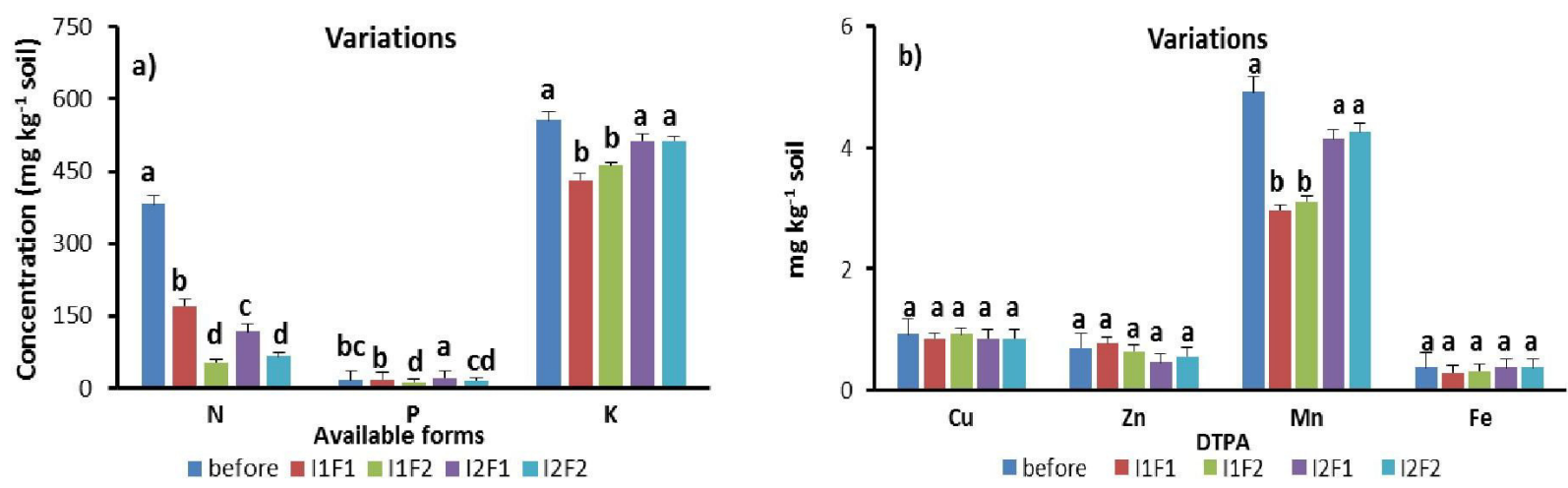

Fig. 1. Levels of nutrient elements in soil before hemp sowing and after the crop harvest at soil depth $0-30 \mathrm{~cm}$; I1F1 (100\% ETo

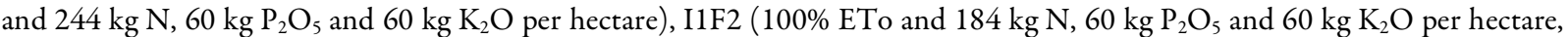
I2F1 (60\% ETo and $244 \mathrm{~kg} \mathrm{~N}, 60 \mathrm{~kg} \mathrm{P}_{2} \mathrm{O}_{5}$ and $60 \mathrm{~kg} \mathrm{~K} \mathrm{O}_{2}$ per hectare), I2F2 (60\% ETo and $184 \mathrm{~kg} \mathrm{~N}, 60 \mathrm{~kg} \mathrm{P} \mathrm{O}_{5}$ and $60 \mathrm{~kg} \mathrm{~K} \mathrm{O}$ per hectare); Data represent the average means \pm standard deviation, $\mathrm{n}=(4)$; For each chemical property of soil, columns with the same letter do not differ significantly according to the Tukey's test $(\mathrm{P}=0.05)$ 

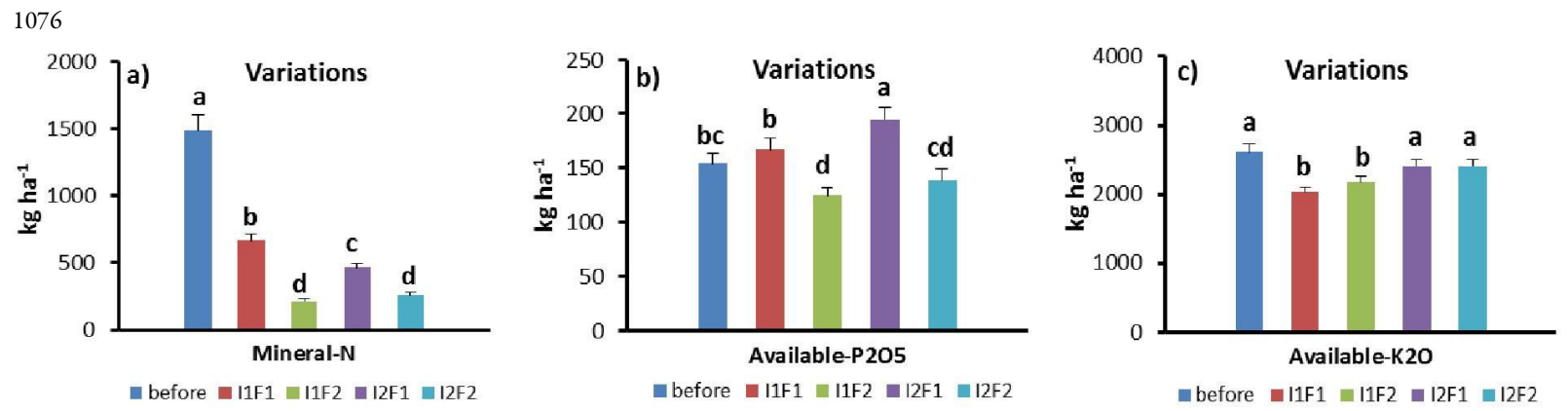

Fig. 2. Inorganic elements availability in the soil at depth (0-30) cm during growing period; Before, start of growing period; I1F1, I1F2, I2F1, and I2F2, end of growing period; Added irrigation and fertilization, I1F1 (100\% ETo and $244 \mathrm{~kg} \mathrm{~N}, 60 \mathrm{~kg} \mathrm{P}_{2} \mathrm{O}_{5}$ and $60 \mathrm{~kg} \mathrm{~K} \mathrm{O}_{2} \mathrm{O}$ per hectare), I1F2 (100\% ETo and $184 \mathrm{~kg} \mathrm{~N}, 60 \mathrm{~kg} \mathrm{P}_{2} \mathrm{O}_{5}$ and $60 \mathrm{~kg} \mathrm{~K} \mathrm{O}_{2}$ per hectare, I2F1 (60\% ETo and $244 \mathrm{~kg} \mathrm{~N}$, $60 \mathrm{~kg} \mathrm{P}_{2} \mathrm{O}_{5}$ and $60 \mathrm{~kg} \mathrm{~K} \mathrm{O}_{2}$ per hectare), I2F2 (60\% ETo and $184 \mathrm{~kg} \mathrm{~N}, 60 \mathrm{~kg} \mathrm{P}_{2} \mathrm{O}_{5}$ and $60 \mathrm{~kg} \mathrm{~K} \mathrm{O}_{2}$ per hectare);Data represent the average means \pm standard deviation, $n=(4)$; For each chemical property of soil, columns with the same letter do not differ significantly according to the Tukey's test $(\mathrm{P}=0.05)$

\section{Mineral composition of hempleaves}

The mineral composition of hemp leaves, grown under the environmental conditions of central Greece, is shown in Table 3 and Fig. 3. Among the applied treatments, I1F2 showed the highest nitrogen concentration in the hemp leaves. This is probably due to the lower inorganic nitrogen concentration in the soil for the treatment IIF2 at the end of the growing season (Table 2 and Fig. 2). Comparing the treatments where the highest level of irrigation $(100 \% \mathrm{ETo})$ was applied with the two $\mathrm{N}$-fertilization levels (I1F1 and I1F2), the treatment I1F2 showed the highest nitrogen concentration in the hemp leaves. This is probably due to lower biomass production and the existence of lower inorganic nitrogen concentration in the soil at the end of the growing season for the treatment I1F2 (Table 3 and Fig. $3)$. Comparing the treatments where the lowest level of irrigation $(60 \% \mathrm{ETo})$ was applied, with the two $\mathrm{N}$ fertilization levels (I2F1 and I2F2), I2F1 showed highest nitrogen concentration in the hemp leaves. This is probably due to the application of highest level fertilization of nitrogen in treatment I2F1 and the same amount biomass production observed between the two treatments.

Moreover, hemp leaves in the treatments where the highest irrigation level (100\% ETo) was applied, compared to the treatments with the lowest applied irrigation level (60\% ETo), showed highest potassium concentration. This is probably due to the existence of lower potassium concentration in the soil at the end of the growing season combined with the higher uptake of potassium from the hemp leaves, in the treatments where the highest level of irrigation was applied (Table 1 and 5; Fig. 1 and Fig. 6). Furthermore, no effect of the two irrigation levels was observed in $\mathrm{Ca}, \mathrm{Mg}$ and $\mathrm{P}$-concentrations in the hemp leaves (Table 3 and Fig. 3).

Therefore, the hemp cultivation under the environmental conditions of central Greece, for treatment I1F1 where was applied the highest irrigation and Nfertilization level, showed highest biomass production, although not observed highest $\mathrm{N}$ and $\mathrm{K}$ concentration in the leaves (Table 4 and Fig. 4).

The results showed that for the studied macronutrients, the hemp leaves had highest in $\mathrm{N}$ concentration, followed by $\mathrm{K}, \mathrm{Ca}, \mathrm{Mg}$ and $\mathrm{P}$, in all treatments (Table 3 and Fig. 3). These results are similar to those reported by other authors for different hemp varieties in central and south Europe (Ivanyi, 2011; Angelini et al., 2014). In particular, the results in the leaves of 'Fibranova' variety showed highest $\mathrm{Mg}$ and $\mathrm{P}$ concentration, compared with the leaves of same variety grown under the environmental conditions of central Italy, while showed similar in $\mathrm{N}, \mathrm{Ca}$ and $\mathrm{K}$ concentration (Angelini et al., 2014).

There is little information on the micronutrients concentrations at hemp leaves. In these results, regarding in $\mathrm{Fe}, \mathrm{Cu}, \mathrm{Zn}, \mathrm{Mn}$ and Mo concentrations in hemp leaves, no effect of the irrigation levels was observed. The results showed highest $\mathrm{Fe}$ concentration, followed by $\mathrm{Mn}, \mathrm{Zn}, \mathrm{Cu}$ and Mo, in all treatments (Table 3 and Fig. 3). Moreover, these results showed lower copper and zinc content in the leaves compared to some varieties grown in Ethiopia and Pakistan (Ghani et al., 2012; Zerihun et al., 2015). Furthermore, the hemp leaves of the study, showed lower $\mathrm{Cu}$ and $\mathrm{Fe}$ concentration, similar in $\mathrm{Zn}$ and $\mathrm{Mo}$, and highest $\mathrm{Mn}$ concentration, compared with the leaves of some varieties grown under the environmental conditions of central Italy, including of 'Fibranova' variety (Angelini $e t$ al., 2014).

The accumulation of the mineral elements in the leaves may be related with factors as the mobility of the elements in the plant, the rate of uptake of the nutrients by the roots the availability of the elements in the soil solution, the climatic conditions, and the variety (Benner and Bazzaz, 1988).

According to previous studies (Mengel et al., 2001), the accumulation tendencies of nutrients to the various plant organs, may indicate synergy or competition between the nutrients, and the various plants organs to have different allocation of nutrients.

\section{Dry yield and nutrient uptake from the hemp leaves}

The harvest was carried out at flowering stage, in July and August 2017. Plants from each treatment were hand cut at $6 \mathrm{~cm}$ from soil. The aerial part of the plant was separated in stem and leaves and allowed to dry into in oven at $59{ }^{\circ} \mathrm{C}$ for the air dry weight determination. The dry biomass hemp yield of, is shown in Table 4 and Fig. 4 . The total dry hemp biomass for all treatments ranged from 12.28 to 15.41 ton $\mathrm{ha}^{-1}$, while the treatment I1F1 showed the highest dry biomass yield. 
Table 3. Mineral composition of hemp leaves at different cultivation practices

\begin{tabular}{|c|c|c|c|c|}
\hline \multirow{2}{*}{ Mineral elements in hemp leaves } & \multicolumn{4}{|c|}{ Treatments } \\
\hline & IIF1 & IIF2 & $\mathrm{I} 2 \mathrm{~F} 1$ & I2F2 \\
\hline$N\left(\mathrm{~g} \mathrm{~kg}^{-1} \mathrm{dw}\right)$ & $28.360 \pm 1.25^{\mathrm{c}}$ & $35.118 \pm 1.59^{\mathrm{a}}$ & $31.356 \pm 1.40^{b}$ & $27.998 \pm 1.24^{c}$ \\
\hline$P \quad\left(\mathrm{~g} \mathrm{~kg}^{-1} \mathrm{dw}\right)$ & $3.326 \pm 0.17^{\mathrm{ab}}$ & $3.696 \pm 0.17^{\mathrm{a}}$ & $3.481 \pm 0.20^{\mathrm{ab}}$ & $3.006 \pm 0.16^{b}$ \\
\hline $\mathrm{K}\left(\mathrm{g} \mathrm{kg}^{-1} \mathrm{dw}\right)$ & $21.826 \pm 0.81^{\mathrm{b}}$ & $25.647 \pm 0.95^{\mathrm{a}}$ & $18.006 \pm 0.62^{\mathrm{d}}$ & $19.654 \pm 0.69^{c}$ \\
\hline $\mathrm{Ca}\left(\mathrm{g} \mathrm{kg}^{-1} \mathrm{dw}\right)$ & $21.7 \pm 0.78^{\mathrm{a}}$ & $21.2 \pm 0.82^{\mathrm{ab}}$ & $19.6 \pm 0.74^{b c}$ & $20.2 \pm 0.79^{\mathrm{b}}$ \\
\hline $\mathrm{Mg}\left(\mathrm{g} \mathrm{kg}^{-1} \mathrm{dw}\right)$ & $8.75 \pm 0.40^{\mathrm{a}}$ & $8.84 \pm 0.39^{\mathrm{a}}$ & $8.55 \pm 0.41^{a}$ & $8.72 \pm 0.39^{a}$ \\
\hline $\mathrm{Na}\left(\mathrm{mg} \mathrm{kg}^{-1} \mathrm{dw}\right)$ & $159.6 \pm 7.16^{a}$ & $171.8 \pm 8.81^{\mathrm{a}}$ & $159.6 \pm 8.19^{\mathrm{a}}$ & $159.6 \pm 8.19^{\mathrm{a}}$ \\
\hline $\mathrm{Cu}\left(\mathrm{mg} \mathrm{kg}^{-1} \mathrm{dw}\right)$ & $4.78 \pm 0.27^{b}$ & $6.96 \pm 0.51^{a}$ & $6.37 \pm 0.42^{\mathrm{a}}$ & $4.78 \pm 0.30^{\mathrm{b}}$ \\
\hline $\mathrm{Zn} \quad\left(\mathrm{mg} \mathrm{kg}^{-1} \mathrm{dw}\right)$ & $27.9 \pm 2.08^{\mathrm{ab}}$ & $30.2 \pm 1.88^{\mathrm{a}}$ & $23.9 \pm 1.82^{\mathrm{b}}$ & $25.6 \pm 1.81^{\mathrm{b}}$ \\
\hline $\operatorname{Mn}\left(\mathrm{mg} \mathrm{kg}^{-1} \mathrm{dw}\right)$ & $42.6 \pm 3.56^{b}$ & $56.2 \pm 4.23^{\mathrm{a}}$ & $44.6 \pm 3.66^{b}$ & $50.4 \pm 3.85^{\mathrm{ab}}$ \\
\hline $\mathrm{Fe}\left(\mathrm{mg} \mathrm{kg}^{-1} \mathrm{dw}\right)$ & $129.0 \pm 8.60^{\mathrm{a}}$ & $129.0 \pm 9.63^{\mathrm{a}}$ & $129.0 \pm 9.56^{\mathrm{a}}$ & $139.8 \pm 10.92^{\mathrm{a}}$ \\
\hline Mo $\left(\mathrm{mg} \mathrm{kg}^{-1} \mathrm{dw}\right)$ & $1.85 \pm 0.13^{\mathrm{a}}$ & $2.07 \pm 0.12^{\mathrm{a}}$ & $1.9 \pm 0.14^{a}$ & $2.10 \pm 0.14^{a}$ \\
\hline \multicolumn{5}{|c|}{$\begin{array}{l}\text { Data represent average means and } \mathrm{SE} \text { deviation, } \mathrm{n}=(4) ; \text { For each chemical property of leaves hemp, lines of table with the same letter do not differ significantly } \\
\text { according to the Tukey's test }(\mathrm{P}=0.05) \text {. Il } 1=100 \% \mathrm{ETo} ; \mathrm{I}=60 \% \mathrm{ETo} ; \mathrm{Fl}=244 \mathrm{~kg} \mathrm{~N}, 60 \mathrm{~kg} \mathrm{P} \mathrm{P}_{2} \mathrm{O} \text { and } 60 \mathrm{~kg} \mathrm{~K} \mathrm{O}_{2} \mathrm{O} \text { per hectare; } \mathrm{F} 2=184 \mathrm{~kg} \mathrm{~N}, 60 \mathrm{~kg} \mathrm{P} \mathrm{P}_{2} \text { and } 60 \mathrm{~kg} \mathrm{~K} \mathrm{~K}_{2} \mathrm{O} \text { per } \\
\text { hectare }\end{array}$} \\
\hline \multirow{2}{*}{ Dry Yield } & \multicolumn{4}{|c|}{ Treatments } \\
\hline & IIF1 & IIF2 & I2F1 & $\mathrm{I} 2 \mathrm{~F} 2$ \\
\hline Total dry yield & $15.41 \pm 0.950^{2}$ & $12.28 \pm 0.777^{b}$ & $12.73 \pm 0.827^{\mathrm{b}}$ & $12.83 \pm 0.839^{b}$ \\
\hline leaves dry yield & $2.407 \pm 0.145^{\mathrm{a}}$ & $2.291 \pm 0.143^{\mathrm{a}}$ & $2.020 \pm 0.132^{b}$ & $2.208 \pm 0.152^{\mathrm{ab}}$ \\
\hline $\begin{array}{l}\text { leaves dry biomass \% } \\
\text { of total plant biomass }\end{array}$ & 15.62 & 18.66 & 15.87 & 17.21 \\
\hline \multicolumn{5}{|l|}{ Mineral element uptakes } \\
\hline $\mathrm{N}$ & $68.26 \pm 2.98^{b}$ & $80.46 \pm 3.64^{a}$ & $63.34 \pm 2.83^{\mathrm{bc}}$ & $61.82 \pm 2.74^{\mathrm{c}}$ \\
\hline$P$ & $8.01 \pm 0.41^{\mathrm{ab}}$ & $8.47 \pm 0.39^{\mathrm{a}}$ & $7.03 \pm 0.41^{\mathrm{bc}}$ & $6.64 \pm 0.35^{\mathrm{c}}$ \\
\hline $\mathrm{K}$ & $52.54 \pm 1.95^{\mathrm{a}}$ & $58.76 \pm 2.18^{\mathrm{a}}$ & $36.37 \pm 1.25^{\mathrm{c}}$ & $43.40 \pm 1.52^{b}$ \\
\hline $\mathrm{Ca}$ & $52.23 \pm 1.88^{\mathrm{a}}$ & $48.57 \pm 1.88^{\mathrm{ab}}$ & $39.59 \pm 1.50^{c}$ & $44.60 \pm 1.75^{\mathrm{bc}}$ \\
\hline $\mathrm{Mg}$ & $21.06 \pm 0.96^{a}$ & $20.25 \pm 0.89^{\mathrm{ab}}$ & $17.27 \pm 0.83^{c}$ & $19.25 \pm 0.86^{b}$ \\
\hline $\mathrm{Na}$ & $0.384 \pm 0.017^{\mathrm{a}}$ & $0.394 \pm 0.020^{\mathrm{a}}$ & $0.322 \pm 0.017^{\mathrm{b}}$ & $0.352 \pm 0.018^{\mathrm{ab}}$ \\
\hline $\mathrm{Cu}$ & $0.012 \pm 0.001^{\mathrm{a}}$ & $0.016 \pm 0.001^{\mathrm{a}}$ & $0.015 \pm 0.001^{a}$ & $0.011 \pm 0.001^{a}$ \\
\hline $\mathrm{Zn}$ & $0.067 \pm 0.005^{\mathrm{a}}$ & $0.069 \pm 0.004^{\mathrm{a}}$ & $0.048 \pm 0.004^{b}$ & $0.057 \pm 0.004^{\mathrm{b}}$ \\
\hline $\mathrm{Mn}$ & $0.103 \pm 0.009^{\mathrm{ab}}$ & $0.129 \pm 0.010^{\mathrm{a}}$ & $0.090 \pm 0.007^{\mathrm{b}}$ & $0.111 \pm 0.009^{\mathrm{ab}}$ \\
\hline $\mathrm{Fe}$ & $0.311 \pm 0.021^{\mathrm{a}}$ & $0.296 \pm 0.022^{\mathrm{ab}}$ & $0.261 \pm 0.019^{\mathrm{b}}$ & $0.309 \pm 0.024^{\mathrm{a}}$ \\
\hline Mo & $0.004 \pm 0.001^{\mathrm{a}}$ & $0.005 \pm 0.001^{a}$ & $0.004 \pm 0.001^{a}$ & $0.005 \pm 0.001^{a}$ \\
\hline
\end{tabular}

Data represent average means and SE deviation, $\mathrm{n}=(4)$; For each chemical property and each dry yield, lines of table with the same letter do not differ significantly according to the Tukey's test $(\mathrm{P}=0.05)$. $\mathrm{Il}=100 \% \mathrm{ETo} ; \mathrm{I}=60 \% \mathrm{ETo} ; \mathrm{F} 1=244 \mathrm{~kg} \mathrm{~N}, 60 \mathrm{~kg} \mathrm{P}_{2} \mathrm{O}_{5}$ and $60 \mathrm{~kg} \mathrm{~K} 2 \mathrm{O}$ per hectare; $\mathrm{F} 2=184 \mathrm{~kg} \mathrm{~N}, 60 \mathrm{~kg} \mathrm{P}_{2} \mathrm{O}_{5}$ and $60 \mathrm{~kg} \mathrm{~K} 2 \mathrm{O}$ per hectare
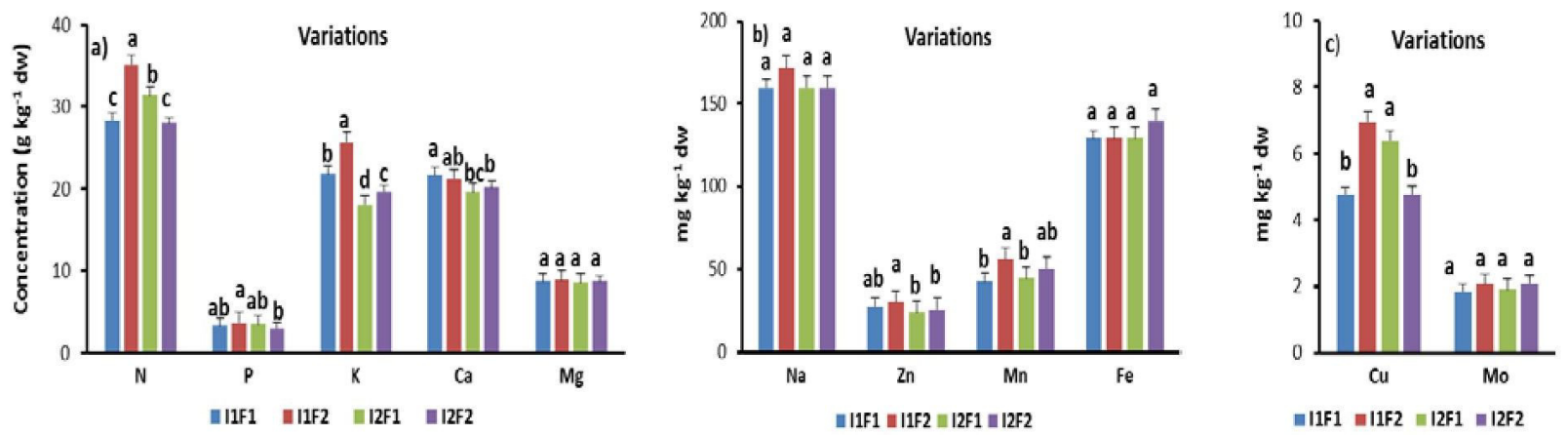

Fig. 3. Mineral composition of hemp leaves at different cultivation practices; I1F1 (100\% ETo and $244 \mathrm{~kg} \mathrm{~N}, 60 \mathrm{~kg} \mathrm{P}_{2} \mathrm{O}_{5}$ and 60 $\mathrm{kg} \mathrm{K}_{2} \mathrm{O}$ per hectare), I1F2 (100\% ETo and $184 \mathrm{~kg} \mathrm{~N}, 60 \mathrm{~kg} \mathrm{P}_{2} \mathrm{O}_{5}$ and $60 \mathrm{~kg} \mathrm{~K} \mathrm{O}_{2}$ per hectare, I2F1 (60\% ETo and $244 \mathrm{~kg} \mathrm{~N}, 60$ $\mathrm{kg} \mathrm{P}_{2} \mathrm{O}_{5}$ and $60 \mathrm{~kg} \mathrm{~K} \mathrm{O}_{2}$ per hectare), I2F2 (60\% ETo and $184 \mathrm{~kg} \mathrm{~N}, 60 \mathrm{~kg} \mathrm{P}{ }_{2} \mathrm{O}_{5}$ and $60 \mathrm{~kg} \mathrm{~K}_{2} \mathrm{O}$ per hectare); Data represent the average means \pm standard deviation, $\mathrm{n}=(4)$; For each chemical property of hemp leaves, columns with the same letter do not differ significantly according to the Tukey's test $(\mathrm{P}=0.05)$ 
1078
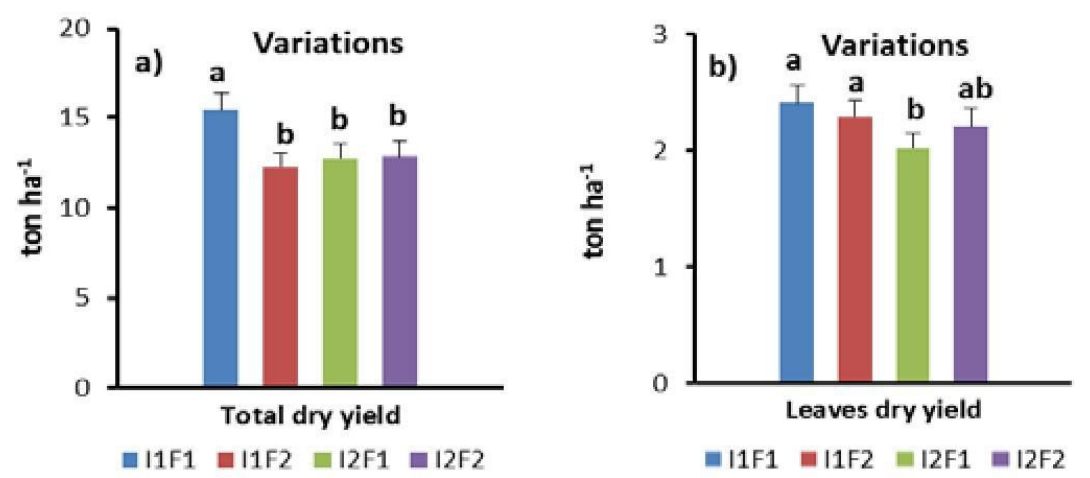

Fig. 4. Total dry biomass and leaves dry biomass of hemp at different cultivation practices; I1F1 (100\% ETo and $244 \mathrm{~kg} \mathrm{~N}, 60 \mathrm{~kg}$ $\mathrm{P}_{2} \mathrm{O}_{5}$ and $60 \mathrm{~kg} \mathrm{~K} \mathrm{O}_{2}$ per hectare), I1F2 (100\% ETo and $184 \mathrm{~kg} \mathrm{~N}, 60 \mathrm{~kg} \mathrm{P} \mathrm{O}_{5}$ and $60 \mathrm{~kg} \mathrm{~K} \mathrm{O}_{2}$ per hectare, I2F1 (60\% ETo and $244 \mathrm{~kg} \mathrm{~N}, 60 \mathrm{~kg} \mathrm{P}_{2} \mathrm{O}_{5}$ and $60 \mathrm{~kg} \mathrm{~K} 2 \mathrm{O}$ per hectare), I2F2 (60\% ETo and $184 \mathrm{~kg} \mathrm{~N}, 60 \mathrm{~kg} \mathrm{P}_{2} \mathrm{O}_{5}$ and $60 \mathrm{~kg} \mathrm{~K} \mathrm{O}_{2}$ per hectare); Data represent the average means \pm standard deviation, $n=(4)$; For dry yield of hemp leaves and total biomass, columns with the same letter do not differ significantly according to the Tukey's test $(P=0.05)$

The dry biomass of leaves ranged from 2.020 to 2.407 ton $\mathrm{ha}^{-1}$. The treatment I1F1 where the highest levels of irrigation and $\mathrm{N}$-fertilization was applied, showed highest dry biomass yield of leaves, compared to treatment I2F1 where the lower level of irrigation was applied and the highest level of $\mathrm{N}$-fertilization. Furthermore, the dry biomass of leaves in all treatments constitute by 15.62 to $18.66 \%$ of total plant biomass.

The mineral elements uptake from the hemp leaves, are shown in Table 4 and Fig. 5. Table 5 and Fig. 6, shows the mineral element uptake from hemp leaves for the production of one ton dry biomass of leaves.

Among the studied treatments, for the production of one ton dry biomass of leaves required the following amounts: The higher amount $\mathrm{N}(35.1 \mathrm{~kg})$ for treatment I1F2 and the lower amount N (28.0 kg) for treatment I2F2, the higher amount $\mathrm{P}(3.7 \mathrm{~kg})$ for treatment I1F2 and the lower amount $\mathrm{P}(3.01 \mathrm{~kg})$ for treatment I2F2, the higher amount $\mathrm{K}(25.65 \mathrm{~kg})$ for treatment I1F2 and the lower amount $\mathrm{K}(18.01 \mathrm{~kg})$ for treatment $\mathrm{I} 2 \mathrm{~F} 1$, the higher amount $\mathrm{Ca}(21.70 \mathrm{~kg})$ for treatment $\mathrm{IF} 1$ and the lower amount Ca $(19.60 \mathrm{~kg})$ for treatment I2F1. Furthermore, magnesium uptake from the hemp leaves did not show statistically significant differences between treatments. The average amounts magnesium required to produce one ton dry biomass of hemp leaves is $8.59 \mathrm{~kg}$. Generally, under the environmental conditions of central Greece, the irrigation of $100 \%$ ETo requires higher amounts of $\mathrm{N}, \mathrm{P}, \mathrm{K}$ and $\mathrm{Ca}$, compared to the irrigation of $60 \% \mathrm{ET}$, for the production of one ton dry biomass of leaves.

The results of this study showed high requirements of the hemp leaves in nutrients. Similar results for high requirements of the hemp leaves in nutrients were obtained in literature (Bócsa and Karus, 1998; Angelini et al., 2014). Therefore, for production of one ton dry biomass of hemp leaves required highest uptake of $\mathrm{N}$, followed by $\mathrm{Ca}, \mathrm{K}, \mathrm{Mg}$ and $P$ in all treatments.

The micronutrients are essential in small amounts in the hemp leaves. The results showed that no effect of the two irrigation levels was observed in $\mathrm{Cu}, \mathrm{Mn}, \mathrm{Fe}$ and $\mathrm{Mo}$ concentrations in the hemp leaves (Table 5 and Fig. 6).The average amounts micronutrients required to produce one ton dry biomass of leaves are $0.294 \mathrm{~kg} \mathrm{Fe}, 0.108 \mathrm{~kg} \mathrm{Mn}$, $0.013 \mathrm{~kg} \mathrm{Cu}$ and $0.0045 \mathrm{~kg} \mathrm{Mo.} \mathrm{Furthermore,} \mathrm{for} \mathrm{the}$ production of one ton dry biomass of leaves, higher amount $\mathrm{Zn}(0.068 \mathrm{~kg})$ required for the irrigation level of $100 \%$ ETo and lower amount $\mathrm{Zn}(0.052 \mathrm{~kg})$ for the irrigation level of 60\% ETo (Table 5 and Fig. 6).

According to other studies, leaves contribute significantly to the overall uptake of the plants in $\mathrm{N}, \mathrm{Mg}$, $\mathrm{Ca}, \mathrm{P}, \mathrm{Zn}$ and $\mathrm{Mn}$ by $66 \%, 59 \%, 58 \%, 53 \%, 50 \%$, and $42 \%$, respectively. The contribution of leaves to the overall uptake of the plants for the elements $\mathrm{K}, \mathrm{Cu}$, and Mo it's about 33\% (Angelini et al., 2014).

Table 5. Mineral element uptakes $(\mathrm{kg})$ from the hemp leaves to produce one ton dry biomass of leaves at different cultivation practices

\begin{tabular}{|c|c|c|c|c|}
\hline \multirow{2}{*}{ Mineral element uptakes (kg) } & \multicolumn{4}{|c|}{ Treatments } \\
\hline & I1F1 & I1F2 & $\mathrm{I} 2 \mathrm{~F} 1$ & $\mathrm{I} 2 \mathrm{~F} 2$ \\
\hline $\mathrm{N}$ & $28.36 \pm 1.24^{b c}$ & $35.12 \pm 1.59^{\mathrm{a}}$ & $31.36 \pm 1.40^{\mathrm{b}}$ & $28.00 \pm 1.24^{c}$ \\
\hline $\mathrm{P}$ & $3.33 \pm 0.17^{\mathrm{ab}}$ & $3.70 \pm 0.17^{\mathrm{a}}$ & $3.48 \pm 0.20^{\mathrm{a}}$ & $3.01 \pm 0.16^{b}$ \\
\hline $\mathrm{K}$ & $21.83 \pm 0.81^{\mathrm{b}}$ & $25.65 \pm 0.95^{\mathrm{a}}$ & $18.01 \pm 0.62^{c}$ & $19.66 \pm 0.69^{\mathrm{c}}$ \\
\hline $\mathrm{Ca}$ & $21.70 \pm 0.78^{\mathrm{a}}$ & $21.20 \pm 0.82^{\mathrm{ab}}$ & $19.60 \pm 0.74^{\mathrm{c}}$ & $20.20 \pm 0.79^{\mathrm{bc}}$ \\
\hline $\mathrm{Mg}$ & $8.75 \pm 0.40^{\mathrm{a}}$ & $8.34 \pm 0.37^{\mathrm{a}}$ & $8.55 \pm 0.41^{\mathrm{a}}$ & $8.72 \pm 0.40^{\mathrm{a}}$ \\
\hline $\mathrm{Na}$ & $0.159 \pm 0.007^{\mathrm{a}}$ & $0.172 \pm 0.009^{\mathrm{a}}$ & $0.159 \pm 0.008^{\mathrm{a}}$ & $0.159 \pm 0.008^{\mathrm{a}}$ \\
\hline $\mathrm{Cu}$ & $0.005 \pm 0.001^{\mathrm{a}}$ & $0.007 \pm 0.001^{\mathrm{a}}$ & $0.007 \pm 0.001^{\mathrm{a}}$ & $0.005 \pm 0.001^{\mathrm{a}}$ \\
\hline $\mathrm{Zn}$ & $0.028 \pm 0.002^{\mathrm{a}}$ & $0.030 \pm 0.002^{\mathrm{a}}$ & $0.024 \pm 0.002^{b}$ & $0.026 \pm 0.002^{\mathrm{ab}}$ \\
\hline $\mathrm{Mn}$ & $0.043 \pm 0.004^{\mathrm{a}}$ & $0.056 \pm 0.004^{\mathrm{a}}$ & $0.045 \pm 0.004^{\mathrm{a}}$ & $0.050 \pm 0.004^{\mathrm{a}}$ \\
\hline $\mathrm{Fe}$ & $0.129 \pm 0.009^{\mathrm{a}}$ & $0.129 \pm 0.010^{\mathrm{a}}$ & $0.129 \pm 0.009^{a}$ & $0.140 \pm 0.011^{\mathrm{a}}$ \\
\hline Mo & $0.002 \pm 0.0003^{\mathrm{a}}$ & $0.002 \pm 0.0003^{\mathrm{a}}$ & $0.002 \pm 0.0003^{\mathrm{a}}$ & $0.002 \pm 0.0003^{\mathrm{a}}$ \\
\hline
\end{tabular}



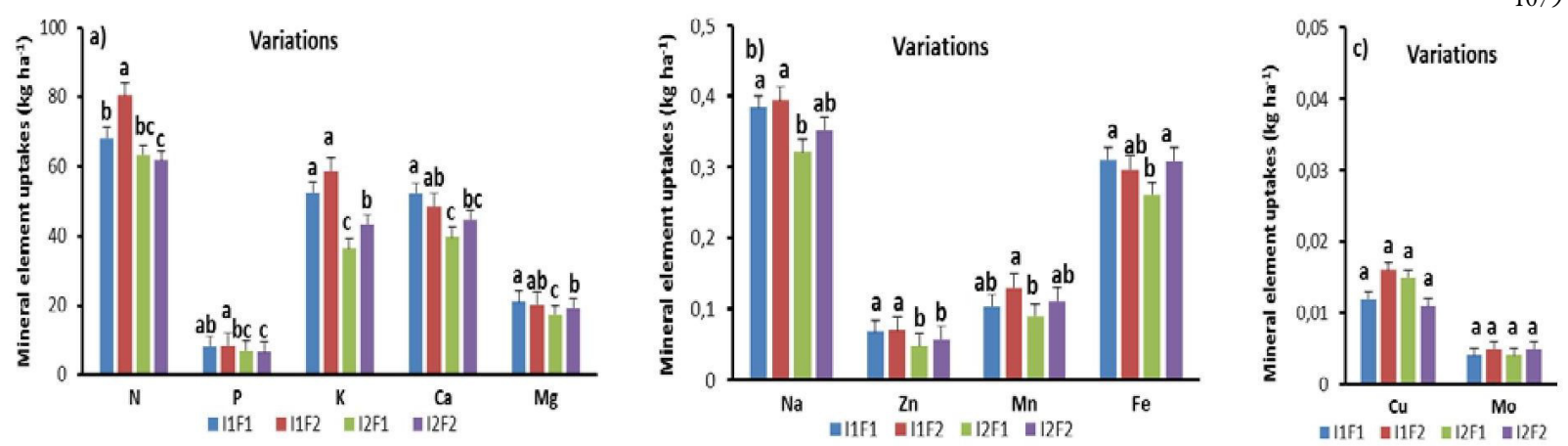

Fig. 5. Mineral element uptakes from the hemp leaves at different cultivation practices; I1F1 (100\% ETo and $244 \mathrm{~kg}$ N, $60 \mathrm{~kg}$ $\mathrm{P}_{2} \mathrm{O}_{5}$ and $60 \mathrm{~kg} \mathrm{~K} \mathrm{O}_{2}$ per hectare), I1F2 (100\% ETo and $184 \mathrm{~kg} \mathrm{~N}, 60 \mathrm{~kg} \mathrm{P}_{2} \mathrm{O}_{5}$ and $60 \mathrm{~kg} \mathrm{~K} \mathrm{O}_{2}$ per hectare, I2F1 (60\% ETo and $244 \mathrm{~kg} \mathrm{~N}, 60 \mathrm{~kg} \mathrm{P}_{2} \mathrm{O}_{5}$ and $60 \mathrm{~kg} \mathrm{~K} \mathrm{O}_{2} \mathrm{O}$ per hectare), I2F2 (60\% ETo and $184 \mathrm{~kg} \mathrm{~N}, 60 \mathrm{~kg} \mathrm{P}_{2} \mathrm{O}_{5}$ and $60 \mathrm{~kg} \mathrm{~K} \mathrm{O}$ per hectare); Data represent the average means \pm standard deviation, $n=(4)$; For each chemical property of hemp leaves, columns with the same letter do not differ significantly according to the Tukey's test $(\mathrm{P}=0.05)$
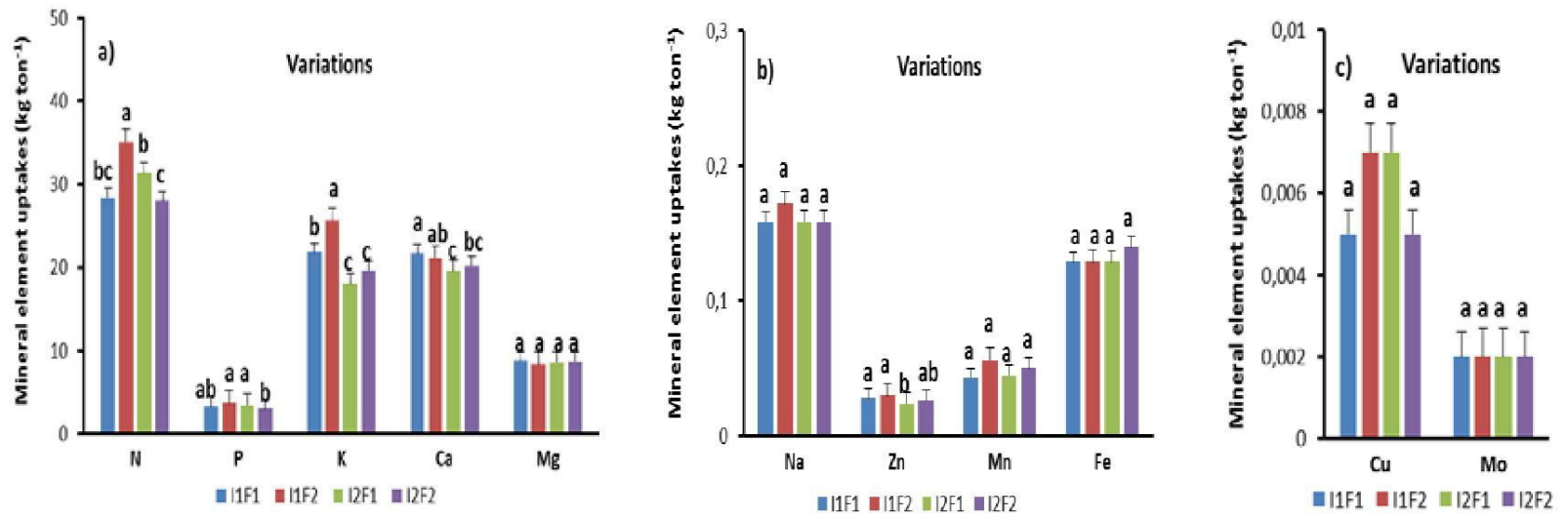

Fig. 6. Mineral element uptakes $(\mathrm{kg})$ from the hemp leaves to produce one ton dry biomass of leaves at different cultivation practices; I1F1 (100\% ETo and $244 \mathrm{~kg} \mathrm{~N}, 60 \mathrm{~kg} \mathrm{P}_{2} \mathrm{O}_{5}$ and $60 \mathrm{~kg} \mathrm{~K} 2 \mathrm{O}$ per hectare), I1F2 (100\% ETo and $184 \mathrm{~kg} \mathrm{~N}, 60 \mathrm{~kg} \mathrm{P}_{2} \mathrm{O}_{5}$

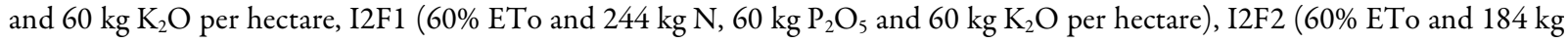
$\mathrm{N}, 60 \mathrm{~kg} \mathrm{P}_{2} \mathrm{O}_{5}$ and $60 \mathrm{~kg} \mathrm{~K} \mathrm{O}_{2}$ per hectare); Data represent the average means \pm standard deviation, $\mathrm{n}=(4)$; For each chemical property of hemp leaves, columns with the same letter do not differ significantly according to the Tukey's test $(\mathrm{P}=0.05)$

\section{Conclusions}

These results confirm the effect of the two irrigation and $\mathrm{N}$-fertilization levels on the macro- and micro-nutrient concentration of hemp leaves, under the environmental conditions of central Greece. The application of the highest level of $\mathrm{N}$-fertilization, showed highest nitrogen concentration in hemp leaves at the treatment where the lowest irrigation level (60\% ETo) was used compared to the highest irrigation level (100\% ETo). On the other hand, the application of the lowest $\mathrm{N}$-fertilization level, showed highest nitrogen concentration in hemp leaves at the treatment with the highest irrigation level compared to the lowest irrigation level. The application of the highest irrigation level compared to the lowest irrigation level showed highest potassium concentration in hemp leaves.
Irrespective of the two irrigation and $\mathrm{N}$-fertilization applied levels, the macronutrient required by the leaves of hemp in higher amounts it was the $\mathrm{N}$ followed by $\mathrm{K}, \mathrm{Ca}$, $\mathrm{Mg}$ and $\mathrm{P}$, while from the micronutrients in higher amounts required the Fe. This is probably due to the mobility of the elements in the plant, to the synergy or competition between the nutrients and the fluctuation in irrigation which could affect the availability of nutrients.

The results could contribute optimal fertilizer application and therefore to the reduction of production costs, to achieve more sustainable cultivation.

\section{Conflict of Interest}

The authors declare that there are no conflicts of interest related to this article. 
1080

\section{References}

Amaducci S, Colauzzi M, Bellocchi G, Cosentino SL, Pahkala K, Stomph TJ, Venturi G (2012). Evaluation of a phenological model for strategic decisions for hemp (Cannabis sativa L.) biomass production across European sites. Industrial Crops and Products 37(1):100-110.

Angelini LG, Tavarini S, Cestone B, Beni C (2014).Variation in mineral composition in three different plant organs of five fibre hemp (Cannabis sativa L.) cultivars. Agrochimica 58(1):1-18.

Benner BL, Bazzaz FA (1988). Carbon and mineral element accumulation and allocation in two annual plant species in response to timing of nutrient addition. The Journal of Ecology 76(1):19-40.

Bertoli A, TozziS, Pistelli L, Angelini L G (2010). Fiber hempinflorescences: From crop-residues to essential oil production. Industrial Crops and Products 32(3):329-337.

Bocsa I, Karus M (1998). The cultivation of hemp: botany, varieties, cultivation and harvesting. Hemptech.Sebastopol, CA, USA.

Bouloc P, Van Der Werf HMG (2013). The role of hemp in sustainable development. Hemp: In: Bouloc P, Allegret S, Arnaud L (Eds). Industrial Production and Uses pp 278-289.

Bouyoucos GJ (1962). Hydrometer method improved for making particle size analysis of soils. Agronomy Journal 54(5):464465.

Cosentino SL, Testa G, Scordia D, Copani V (2012). Sowing time and prediction of flowering of different hemp (Cannabissativa L.) genotypes in southern Europe. Industrial Crops and Products 37(1):20-33.

Finnan J, Styles D (2013). Hemp: a more sustainable annual energy crop for climate and energy policy. Energy Policy 58:152-162.

Ghani A, Saeed S, Ali Z, Ahmad I, Ishtiaq M (2012). Heavy metals and nutritional composition of some selected herbal plants of Soon Valley, Khushab, Punjab, Pakistan. African Journal of Biotechnology 11(76):1406414068.

Hakala K, Keskitalo M, Eriksson C, Pitkänen T (2009). Nutrient uptake and biomass accumulation for eleven different field crops. Agricultural and Food Science 18:366-387.

Ivanyi I (2011). Relationship between leaf nutrient concentration and the yield of fiber hemp (Cannabis sativa L.). Research Journal of Agricultural Science 43(3):70-76.

Jones Jr JB, Case VW (1990). Sampling, handling and analyzing plant tissue samples. Sampling, handling and analyzing plant tissue samples. Ed. 3,pp 389427.
Jones Jr LJB(1998). Plant nutrition manual CRC Press. New York.

Mengel K, Kirkby EA, Kosegarten H, Appel T (2001). Principles of plant nutrition. Kluwer Academic Publishers. Dordrecht/Boston/London, pp 464469 .

Mihoc M, Pop G, AlexaE, Radulov I (2012). Nutritive quality of Romanian hemp varieties (Cannabis sativa L.) with special focus on oil and metal contents of seeds. Chemistry Central Journal 6(1):122.

Page AL, Miller RH, Keeney DR (1982). Methods of soil analysis. Part 2: Chemical and microbiological properties. Agronomy, ASA and SSSA, Madison,Wisconsin, USA.

Ryan BF, Joiner BL, CryerJD (2005). MINITAB Handbook: Updated for release 14, 5th edition. Brooks/Cole-Thomson Learning Inc, Kentaky, $\mathrm{KY}$.

Small E, Marcus D (2002). Hemp: a new crop with new uses for North America. Trends in New Crops and New Uses 284326.

Small E, Marcus D (2003). Tetrahydrocannabinol levels in hemp (Cannabis sativa L.) germplasm resources. Economic Botany 57(4):545-558.

Struik PC, Amaducci S, Bullard MJ, Stutterheim NC, Venturi G, Cromack HTH (2000). Agronomy of fiber hemp (Cannabis sativa L.) in Europe. Industrial Crops and Products 11(2-3):107-118.

Tang K, Struik PC, Yin X, Thouminot C, Bjelková M, Stramkale V, AmaducciS (2016). Comparinghemp (Cannabissativa L.) cultivars for dual-purpose production under contrasting environments. Industrial Crops and Products 87:33-44.

Van der WerfHM, Turunen L (2008). The environmental impacts of the production of hemp and flax textile yarn. Industrial Crops and Products 27(1):1-10.

Varian M (1989). Flama atomic absorption spectroscopy. Analytical Methods. Varian Australia. Publ. No: 85-100009-00.

Zatta A, Monti A, Venturi G (2012). Eighty years of studies on industrial hemp in the Po Valley (1930-2010). Journal of Natural Fibers 9(3):180196.

Zerihun A, Chandravanshi BS, Debebe A, Mehari B (2015). Levels of selected metals in leaves of Cannabis sativa L. cultivated in Ethiopia. SpringerPlus 4(1):359. 